\title{
Analisis Determinan Tingkat Pengangguran Terbuka di Pulau Jawa Tahun 2007-2016
}

\author{
(Determinant Analysis of Open Unemployment Rate In Java Island Year 2007-2016)
}

\author{
Wildan Aziz Amrullah, Nanik Istiyani, Fivien Muslihatinningsih* \\ Jurusan Ilmu Ekonomi Studi Pembangunan, Fakultas Ekonomi dan Bisnis, Universitas Jember (UNEJ) \\ Jln. Kalimantan 37, Jember 68121 \\ E-mail: fivien.feb@unej.ac.id
}

\begin{abstract}
Abstrak
Pengangguran merupakan masalah yang kompleks karena mempengaruhi sekaligus dipengaruhi oleh banyak faktor yang saling berinteraksi mengikuti pola yang tidak mudah untuk dipahami. Masalah pengangguran merupakan salah satu akibat dari adanya fenomena ekonomi yang terjadi. Besarnya angka pengangguran dapat dipengaruhi oleh beberapa indikator antara lain besarnya upah yang berlaku, PDRB, dan tingkat inflasi. Tujuan dari penelitian ini adalah untuk mengetahui seberapa besar pengaruh PDRB, Upah Minimum Provinsi dan tingkat inflasi terhadap pengangguran terbuka di setiap provinsi di Pulau Jawa Tahun 2007-2016. Metode analisis yang digunakan adalah model regresi data panel dengan menggunakan pendekatan Fixed Effect Model (FEM). Hasil regresi data panel menunjukkan secara simultan bahwa variabel variabel independen PDRB, Upah Minimum Provinsi, dan inflasi berpengaruh signifikan terhadap variabel dependen tingkat pengangguran terbuka. Hasil analisis uji parsial menunjukkan bahwa PDRB memiliki pengaruh signifikan, Sedangkan Upah Minimum Provinsi dan Inflasi memiliki pengaruh yang tidak signifikan terhadap tingkat pengangguran terbuka periode tahun 2007-2016. Total variasi tingkat pengangguran terbuka di provinsi Pulau Jawa mampu dijelaskan oleh variabel-variabel independen PDRB, UMP dan inflasi sebesar 93,35\%.
\end{abstract}

Kata kunci: Tingkat Pengangguran terbuka,PDRB, Upah Minimum Provinsi, Inflasi.

\begin{abstract}
Unemployment is a complex problem because it's affecting and influenced by many factors that interact with each other following patterns that are not easy to understand. The problem of unemployment is the one result of the existence of economic phenomena that occur. The rate of unemployment can be influenced by several indicators, such as the amount of prevailing wage, The GDP, and inflation rate. The aim of this research is to know how big influence of the GDP, Province Minimum Wage and inflation rate on open unemployment in every province in Java Island Year 2007-2016. The method analysis of this research using Panel data with using Fixed Effect Model (FEM) approach. The result of panel data regression showed simultaneously that the variables of tghe GDP, Province Minimum Wage, and inflation have significant, The result of partial test analysis showed that The GDP has significant influence, while province Minimum Wage and inflation have a negative and insignificant on open unemployment Rate in Java Island period 2007-2016. The total variation in open unemployment rate in Java Island province can be explained by independent variables of PDRB, UMP and inflation at $93.35 \%$.
\end{abstract}

Keywords: Open Unemployment Rate, The GDP, Province Minimum Wage, Inflation.

\section{Pendahuluan}

Salah satu masalah yang sama pada negara berkembang, yaitu kesulitan untuk mengendalikan tingkat pengangguran. Keadaan di negara berkembang seperti Indonesia dalam beberapa tahun ini menunjukkan bahwa pembangunan yang telah dilakukan belum mampu menyediakan kesempatan kerja kepada angkatan kerja yang ada. Hal ini dikarenakan laju pertumbuhan angkatan kerja lebih cepat diandingkan dengan pertumbuhan kesempatan kerja.

Pengangguran merupakan masalah yang kompleks karena mempengaruhi sekaligus dipengaruhi oleh banyak faktor yang saling berinteraksi mengikuti pola yang tidak mudah untuk dipahami. Menurut Samuleson (2008), pengangguran

yang tinggi termasuk kedalam masalah ekonomi dan masalah sosial. Pengangguran merupakan masalah ekonomi karena ketika angka pengangguran meningkat, sebagai dampaknya suatu Negara membuang barang dan jasa yang sebenarnya dapat diproduksi oleh pengangguran. Pengangguran juga merupakan masalah sosial yang besar karena mengakibatkan penderitaan yang besar untuk pekerja yang menganggur yang harus berjuang dengan pendapatan yang berkurang. Biaya ekonomi dari pengangguran jelas besar, namun tidak ada jumlah mata uang yang dapat mengungkapkan secara tepat tentang korban psikologi dan manusia pada saat mereka menganggur.

Perkembangan Tingkat Pengangguran Terbuka masih berfluktuatif pada tahun 2011 hingga tahun 2016 di Indonesia. Pulau Jawa yang merupakan pusat pemerintahan serta memiliki jumlah tenaga kerja yang besar dengan Tingkat Pengangguran Terbuka cukup tinggi bila dibandingkan dengan Provinsi lainnya di Indonesia. Hal ini karena jumlah pengangguran yang ada di Pulau Jawa periode tahun 2011-2016 memberi sumbangsih sebesar 60 - 65 persen dari total keseluruhan tingkat pengangguran terbuka di Indonesia

Jumlah pengangguran di Pulau Jawa mencapai 4.318.783 jiwa dan merupakan jumlah yang besar dengan total angkatan kerja sebesar 73.683.299 jiwa pada tahun 2016. Angka ratarata pengangguran terbuka dari 6 provinsi tersebut yaitu sebesar enam persen dari jumlah angkatan kerja di Pulau

\footnotetext{
* Corresponding author
} 
Jawa tahun 2016. Hal ini berarti penyerapan tenaga kerja masih kurang karena tingkat pengangguran masih cukup tinggi untuk Pulau Jawa. Pertumbuhan yang terjadi pada jumlah penduduk dan jumlah angkatan kerja ternyata tidak diimbangi oleh tingginya penyerapan tenaga kerja yang ada. Akibat dari kurangnya penyerapan tenaga kerja yang tersedia akan menimbulkan tingkat pengangguran terbuka yang tinggi.

Pengangguran terbuka biasanya terjadi pada generasi muda yang baru menyelesaikan pendidikan menengah dan tinggi. Ada kecenderungan mereka yang baru menyelesaikan pendidikan berusaha untuk mencari kerja sesuai dengan keinginan mereka. Keiinginan mereka biasanya bekerja disektor modern atau dikantor. Untuk mendapatkan pekerjaan itu mereka umumnya bersedia untuk menunggu sedikit lebih lama. Tidak menutup kemungkinan mereka berusaha mencari pekerjaan di kota, provinsi atau di daerah yang kegiatan industrinya telah berkembang lebih pesat. Hal Ini yang menyebabkan angka pengangguran terbuka cenderung tinggi di kota atau daerah tersebut. Sebaliknya, angka pengangguran terbuka rendah didaerah atau provinsi yang kegiatan ekonominya masih tertumpu pada sektor tradisional, terlebih jika tingkat pendidikan didaerah itu masih rendah (Mudjadrat, 2006). Dalam pembangunan ekonomi pengangguran merupakan isu penting di Pulau Jawa dan beberapa indikator ekonomi yang mempengaruhi tingkat pengangguran antara lain tingkat upah, PDRB, Inflasi.

Keynes menjelaskan penurunan tingkat upah akan menurunkan pendapatan, sehingga akan menurunkan daya beli masyarakat termasuk pengeluaran agregat masyarakat, dampaknya kapasitas produksi yang berlebih dari produsen yang akan dijual kepada masyarakat akan menjadi mubazir dan merugikan perusahaan. Sehingga perusahaan akan memberhentikan tenaga kerjanya dan penggunaan tenaga kerja penuh (full employment) tidak akan tercapai (Putong, 2007). Apabila tingkat upah naik akan berpengaruh pada penurunan tingkat pengangguran. Dimana, pemerintah masih meyakini bahwa upah minimum juga merupakan cara yang efektif untuk memperbaiki nasib pekerja yang mempunyai penghasilan rendah. Indonesia tidak mungkin menyerahkan penetapan upah pekerja atau buruh kepada mekanisme pasar, hal ini disebabkan di dalam pasar tenaga kerja masih terlihat ketidakseimbangan struktural. Setiap kenaikan tingkat upah akan diikuti oleh turunnya tenaga kerja yang diminta, yang berarti akan menyebabkan bertambahnya pengangguran.

Produk Domestik Regional Bruto (PDRB) atas dasar harga konstan digunakan untuk menunjukkan laju pertumbuhan ekonomi secara keseluruhan dari tahun ke tahun. PDRB merupakan salah satu indikator penting untuk mengetahui peranan dan potensi ekonomi di suatu wilayah dalam periode tertentu. Peran daerah dalam mendukung perekonomian nasional cukup besar namun terkadang tidak sejalan dengan perkembangan perekonomian nasional, peran tersebut menjadi beban optimal. Fenomena perekonomian saat ini cenderung menuntut adanya peran aktif dari para eksekutif untuk lebih banyak menggali potensi perekonomian daerahnya serta memainkan peranan yang lebih besar dalam merangsang aktivitas ekonomi daerah. (safitri, 2011). Pada kenyataannya, PDRB mempunyai pengaruh terhadap jumlah angkatan kerja yang bekerja dengan asumsi apabila nilai PDRB suatu wilayah meningkat, maka jumlah output dalam seluruh unit ekonomi di suatu wilayah akan meningkat. Output yang jumlahnya meningkat akan menyebabkan terjadinya peningkatan permintaan tenaga kerja (Burhanudin, 2015).

Inflasi merupakan suatu proses kenaikan harga-harga yang berlaku dalam suatu perekonomian. Sedangkan tingkat inflasi adalah presentasi kenaikan harga-harga barang dalam periode waktu tertentu (Sukirno, 1994:27). Semakin tingginya tingkat inflasi yang terjadi maka akan berakibat pada tingkat pertumbuhan ekonomi yang menurun sehingga akan terjadi peningkatan terhadap angka pengangguran.

Teori A.W. Phillips muncul karena pada saat tahun 1929, terjadi depresi ekonomi Amerika Serikat, hal ini berdampak pada kenaikan inflasi yang tinggi dan diikuti dengan pengangguran yang tinggi pula. berdasarkan pada fakta itulah A.W. Phillips mengamati hubungan antara tingkat inflasi dengan tingkat pengangguran. Dari hasil pengamatannya, ternyata ada hubungan yang erat antara Inflasi dengan tingkat pengangguran, jika inflasi tinggi, pengangguran pun akan rendah. Hasil pengamatan Phillips ini dikenal dengan kurva Phillip (Ariefta, 2014).

Berdasarkan uraian di atas, maka rumusan masalah dalam penelitian ini adalah Seberapa besar pengaruh Produk Domestik Regional Bruto (PDRB) terhadap tingkat pengangguran terbuka di setiap provinsi di Pulau Jawa? Seberapa besar pengaruh Upah Minimum Provinsi (UMP) terhadap tingkat pengangguran terbuka di setiap provinsi di Pulau Jawa? Seberapa besar pengaruh tingkat Inflasi terhadap tingkat pengangguran terbuka di setiap provinsi di Pulau Jawa?

Kemudian tujuan yang ingin dicapai dari penelitian ini adalah untuk mengetahui seberapa besar pengaruh Produk Domestik Regional Bruto (PDRB) terhadap tingkat pengangguran terbuka di setiap provinsi di Pulau Jawa, untuk mengetahui seberapa besar pengaruh Upah Minimum Provinsi (UMP) terhadap tingkat pengangguran terbuka di setiap provinsi di Pulau Jawa, untuk mengetahui seberapa besar pengaruh tingkat inflasi terhadap tingkat pengangguran terbuka di setiap provinsi di Pulau Jawa.

\section{Metode}

\section{Jenis Penelitian}

Jenis penelitian yang digunakan adalah eksplanatory research, yaitu penelitian yang menjelaskan secara sistematis, faktual dan akurat mengenai suatu objek yang diteliti dan bertujuan untuk mencari ada tidaknya pola hubungan dan sifat hubungan antara dua variabel atau lebih, serta untuk menguji hipotesis bahkan menemukan teori baru (Nazir,2003). Penelitian ini menjelaskan hubungan antara PDRB, UMP, dan Inflasi terhadap Tingkat Pengangguran di setiap Provinsi Pulau Jawa.

\section{Jenis dan Sumber Data}

Jenis data yang digunakan dalam penelitian ini adalah data kuantitatif, yaitu data yang diukur dalam suatu skala numerik (angka). Data kuantitatif ini berupa data runtut waktu (time series) dan cross section yang bersifat kuantitatif atau selama kurun waktu 2007 - 2016 (sepuluh tahun). Dalam penelitian ini menggunakan sumber data sekunder yang dikumpulkan melalui studi litartur baik buku, jurnal penelitian, serta 
sumber data terbitan beberapa instansi tetentu meliputi 6 wilayah penelitian yaitu semua Provinsi Pulau Jawa.

\section{Metode Analisis Data}

Untuk menganalisis pengaruh Pertumbuhan UMP, Pertumbuhan PDRB, dan Tingkat Inflasi terhadap pengangguran di setiap Provinsi Pulau Jawa maka digunakan model regresi data panel

$$
\mathrm{TPT}_{i, \mathrm{t}}=\alpha+\beta_{1} \mathrm{UMP}_{\mathrm{i}, \mathrm{t}}+\beta_{2} \mathrm{PDRB}_{\mathrm{i}, \mathrm{t}}+\beta_{3} \mathrm{INF}_{\mathrm{i}, \mathrm{t}}+\epsilon_{\mathrm{i}, \mathrm{t}}
$$

Dimana :

$$
\begin{array}{ll}
\text { TPT } & =\text { Tingkat Pengangguran Terbuka } \\
\text { UMP } & =\text { Upah Minimum Provinsi } \\
\text { PDRB } & =\text { Produk Domestik Regional Bruto } \\
\text { INF } & =\text { Inflasi } \\
\alpha & =\text { Intercept } \\
\beta \text { it } & =\text { Koefisien variabel } \\
\epsilon & =\text { Error term } \\
\text { I } & =1,2, \ldots, \mathrm{N} \text { (banyaknya sampel/observasi) } \\
\mathrm{t} & =1,2, \ldots, \mathrm{T} \text { (banyaknya waktu) }
\end{array}
$$

Kemudian tiga teknik analisis yang dapat digunakan, yaitu :

\section{Metode Pooled Least Square (PLS)}

Model pooled juga sering disebut sebagai model common atau homogenity. PLS adalah struktur model di mana estimator akan menghasilkan intercept $\alpha$ dan slope $\beta$ sama untuk setiap individu $\left(\alpha_{1}=\alpha_{2}=\alpha_{3}=\ldots=\alpha_{i}\right.$ dan $\left.\beta_{\mathrm{k} 1}=\beta_{\mathrm{k} 2}=\beta_{\mathrm{k} 3}=\ldots=\beta_{\mathrm{ki}}\right)$. Dimana $\mathrm{k}$ adalah jenis variabel dan $\mathrm{i}$ adalah observasi ke-i. Struktur model ini mengasumsikan tidak adanya perbedaan karakteristik Tingkat Pengangguran (TP) di setiap provinsi selama waktu observasi.

\section{Metode Fix Effect Model (FEM)}

FEM merupakan model yang memperhatikan adanya keberagaman (heterogenitas) dari variabel independen menurut individu. Keberagaman individu diketahui melalui intercept $\alpha$ yang berbeda untuk setiap individu. Dampak dari setiap variabel independen dipertahankan sama untuk setiap individu sepanjang waktu observasi $\left(\alpha_{1} \neq \alpha_{2} \neq \alpha_{3} \neq \ldots \neq \alpha_{i}\right.$ dan $\left.\beta_{1 \mathrm{k}}=\beta_{2 \mathrm{k}}=\beta_{3 \mathrm{k}}=\ldots=\beta_{\mathrm{ik}}\right)$. Struktur model ini mengasumsikan adanya perbedaan karakteristik Tingkat Pengangguran (TP) di setiap provinsi selama waktu observasi. Penggunaan kata fixed pada model FEM menunjukkan bahwa faktor penyebab heterogenitas di setiap individu di asumsikan tetap sepanjang waktu observasi. Pengaruh yang tetap dapat dilihat dari penggunaan nilai yang sama (yaitu 1) sepanjang waktu. Nilai 1 ditempatkan pada individu tertentu dan nol untuk individu lainnya.

\section{Metode Random Effect Model (REM)}

Pendekatan random effect mempertimbangkan setiap persamaan karakteristik individu. Penentuan $\alpha$ dan $\beta$ didasarkan pada asumsi bahwa intercepta terdistribusi random antar unit $\mu_{\mathrm{i}}$. dengan kata lain, slope memiliki nilai yang tetap tetapi, intercept bervariasi untuk setiap individu. Dari model ini dapat dilihat bahwa slope $\beta$ memiliki nilai tetap tetapi, intercept $\alpha_{1 \mathrm{i}}$ memiliki nilai yang bervariasi karena pengaruh random $\epsilon_{\mathrm{i}}$ terhadap intercept $\alpha_{1}\left(\alpha_{1 \mathrm{i}}=\alpha_{1}+\epsilon_{\mathrm{i}}\right)$ yang bernilai tetap. Dengan model ini diasumsikan bahwa pengaruh dari setiap individu sama.

Dari ketiga teknik analisis tersebut dipilih salah satu model yang terbaik dengan melakukan pengujian Chow, Hausmann dan Lagrance Multiplier (LM) sebagai berikut.

\section{Uji Chow}

Uji Chow digunakan untuk menentukan model mana yang paling tepat antaraPooled Least Sqaure (PLS) atauFixed Effect Model (FEM) (Nachrowi, 2006).. Pengujian ini dilakukan dengan hipotesis sebagai berikut :

a. $\mathrm{F}_{\text {statistik }} \leq \mathrm{F}_{\text {tabel }}$ atau nilai probabilitas $\mathrm{F}_{\text {statistik }}>$ nilai probabilitas kritis $(\alpha=5 \%)$, maka hipotesis nol $\left(\mathrm{H}_{0}\right)$ diterima. Artinya, tidak terdapat hubungan antara efek individu dengan variabel bebas sehingga model yang digunakan adalah Pooled Least Square(PLS).

b. $\mathrm{F}_{\text {statistik }}>\mathrm{F}_{\text {tabel }}$ atau nilai probabilitas $\mathrm{F}_{\text {statistik }} \leq$ nilai probabilitas kritis $(\alpha=5 \%)$ maka hipotesis nol $\left(\mathrm{H}_{0}\right)$ ditolak dan menerima hipotesis alternatif $\left(\mathrm{H}_{\mathrm{A}}\right)$. Artinya, efek individual berkorelasi dengan variabel bebas sehingga model yang digunakan adalah Fixed Effect Model (FEM).

\section{Uji Hausman}

Uji Hausman dilakukan untuk menentukan metode mana yang paling tepat antara Fixed Effect atau Random Effect. Pengujian ini dilakukan dengan hipotesis sebagai berikut :

a. $\mathrm{Chi}_{\text {statistik }} \leq \mathrm{Chi}_{\text {tabel }}$ atau nilai probabilitas $\mathrm{Chi}_{\text {statistik }}>$ nilai probabilitas kritis $(\alpha=5 \%)$, maka hipotesis nol $\left(\mathrm{H}_{0}\right)$ diterima. Artinya, tidak terdapat hubungan antara efek individu dengan variabel bebas sehingga model yang digunakan adalah Random Effect Model (REM).

b. Jika Chi $i_{\text {statistic }}>\mathrm{Chi}_{\text {tabel }}$ atau nilai probabilitas $\mathrm{Chi}_{\text {statistik }} \leq$ nilai probabilitas kritis $(\alpha=5 \%)$, maka hipotesis nol $\left(\mathrm{H}_{0}\right)$ ditolak dan menerima hipotesis alternatif $\left(\mathrm{H}_{\mathrm{A}}\right)$. Artinya, efek individual berkorelasi dengan variabel bebas sehingga model yang digunakan adalah Fixed Effect Model (FEM).

\section{Uji Lagrance Multiplier (LM)}

Apabila dalam uji Hausmann hasil model yang terbaik adalah Random Effect, maka dilanjutkan dengan uji Lagrance Multiplier (LM) yang dikembangkan oleh Breusch-Pagan. Hal ini untuk mengetahui apakah model Random Effect lebih baik dari metode OLS dan sebaliknya. Uji LM ini di dasarkan pada distribusi chi-squares dengan degree of freedom sebesar jumlah variabel independen (Nachrowi, 2006).

Pengujian ini dilakukan dengan hipotesis sebagai berikut:

a. $\mathrm{LM}_{\text {statistik }} \leq \mathrm{Chi}_{\text {statistik }}$ maka hipotesis nol $\left(\mathrm{H}_{0}\right)$ diterima. Artinya, metode yang digunakan adalah Random Effect.

b. Jika $\mathrm{LM}_{\text {statistic }}>\mathrm{Chi}_{\text {statistik }}$ maka hipotesis nol $\left(\mathrm{H}_{0}\right)$ ditolak dan menerima hipotesis alternatif $\mathrm{H}_{\mathrm{A}}$. Artinya, metode yang paling tepat digunakan adalah Pooled LeastSquare.

Selanjutnya dilakukan uji statistik diantaranya: 


\section{Uji F-Statistik}

Pengujian ini dilakukan untuk mengetahui apakah semua variabel independen mempunyai pengaruh yang sama terhadap variabel dependen. Pengujian yang dilakukan menggunakan uji distribusi $\mathrm{F}$ dengan cara membandingkan antara nilai $\mathrm{F}_{\text {tabel }}$ dengan nilai $\mathrm{F}_{\text {hitung }}$

\section{Uji t-Statistik}

Uji t-parsial pada fungsi regresi $\mathrm{Y}=\mathrm{f}\left(\mathrm{X}_{1}, \mathrm{X}_{2}, \ldots \mathrm{X}_{\mathrm{n}}\right)$ bertujuan untuk membuat kesimpulan mengenai pengaruh masing-masing variabel independen $(\mathrm{X})$ terhadap variabel dependen $(\mathrm{Y})$

\section{Koefisien Dterminasi $\left(\mathrm{R}^{2}\right)$}

Koefisien regresi bertujuan untuk memastikan apakah variabel independen yang terdapat dalam persamaan tersebut secara individu berpengaruh terhadap nilai variabel dependen (uji parsial).Besarnya presentase pengaruh semua variabel independen terhadap nilai variabel dependen dapat diketahui dari besarnya koefisien determinasi $\left(\mathrm{R}^{2}\right)$ persamaan regresi. Besarnya koefisien koefisien determinasi adalah 0 sampai 1

Adapun beberapa uji asumsi klasik yang digunakan dalam penelitian ini, diantaranya:

1. Uji Multikolinieritas;

2. Uji Heterokedastisitas;

3. Uji Normalitas;

4. Uji Autokorelasi.

\section{Hasil dan Pembahasan}

\section{Hasil}

Untuk melihat seberapa besar pengaruh PDRB, UMP dan inflasi terhadap tingkat pengangguran terbuka di semua provinsi Pulau Jawa selama kurun waktu 2007-2016 maka dilakukan estimasi dengan panel data. Hasil estimasi panel data sebagai berikut :

Tabel 1. Perbandingan Estimasi Panel Data Model PLS, FEM dan REM

Dependent Variable: TPT

\begin{tabular}{ccccccc}
\hline Variabel & PLS & Prob. & FEM & Prob. & REM & Prob. \\
\hline C & -1.360834 & 0.9268 & 106.4933 & 0.0000 & 73.99099 & 0.0000 \\
PDRB & 0.634523 & 0.1386 & -7.867119 & 0.0018 & -0.961633 & 0.3592 \\
UMP & 0.019911 & 0.9853 & -0.223318 & 0.8714 & -3.942486 & 0.0000 \\
INF & 0.235683 & 0.1582 & -0.052895 & 0.2705 & -0.041974 & 0.3798 \\
R- & & & & & & \\
squared & 0.067633 & & 0.934933 & & 0.661938 &
\end{tabular}

Sumber : data sekunder diolah, 2017

Berdasarkan hasil estimasi panel data pada Tabel 1 dengan variabel terikat kesempatan kerja, Fixed Effect Model (FEM) menunjukkan hasil yang lebih baik dibandingkan Random Effect Model(REM) dan Pooled Least Square (PLS). Hal ini bisa dilihat dari nilai koefisien regresi dari masing-masing variabel bebasnya. Selain itu, nilai $\mathrm{R}$-square $\left(\mathrm{R}^{2}\right)$ yang lebih baik terdapat pada Fixed Effect Model (FEM) dibandingkan model lainnya. Setelah dilakukan analisis untuk model tersebut, maka untuk memilih model yang terbaik antara Pooled Least Square (PLS), Fixed Effect Model (FEM) dan Random Effect Model (REM) dapat dilakukan dengan uji Chow, Hausman dan Lagrange Multiplier (LM).

Dari hasil pengujian Chow dan Hausman diperoleh model terbaik untuk penelitian ini yaitu Fixed Effect Model (FEM). Hasil estimasi mengenai model terbaik Fixed Effect Model akan dipaparkan dalam Tabel 2 berikut ini.

Tabel 2. Fixed Effect Model (FEM)

\begin{tabular}{lllll}
\hline Variable & Coefficient & Std. Error & t-Statistic & Prob. \\
\hline C & 106.4933 & 12.08490 & 8.812095 & 0.0000 \\
LOGPDRB & -7.867119 & 2.383185 & -3.301094 & 0.0018 \\
LOGUMP & -0.223318 & 1.372932 & -0.162658 & 0.8714 \\
INF & -0.052895 & 0.047484 & -1.113952 & 0.2705
\end{tabular}

Sumber : data sekunder diolah, 2017

Fixed Effect Model(FEM) merupakan model yang memperhatikan adanya keberagaman (heterogenitas) dari variabel independen menurut individu. Keberagaman individu diketahui melalui intercept $\alpha$ yang berbeda untuk setiap individu. Dampak dari setiap variabel independen dipertahankan sama untuk setiap individu sepanjang waktu observasi $\left(\alpha_{1} \neq \alpha_{2} \neq \alpha_{3} \neq \ldots \neq \alpha_{i}\right.$ dan $\left.b_{1 \mathrm{k}}=b_{2 k}=b_{3 k}=\ldots=b_{i k}\right)$. Struktur model ini mengasumsikan adanya perbedaan karakteristik tingkat pengangguran terbuka (TPT) di setiap provinsi selama waktu observasi.

Berdasarkan hasil estimasipanel data pada Tabel 2 dengan menggunakan pendekatan Fixed Effect Model (FEM) diperoleh hasil persamaan:

$\mathrm{TPT}=106.4933-7.867119 * \mathrm{PDRB}-0.223318 * \mathrm{UMP}-$ $0.052895 * \mathrm{INF}+[\mathrm{CX}=\mathrm{F}]$

Persamaan regresi panel data di atas menjelaskan bahwa :

1. Nilai b0 $=106.4933$ menunjukkan bahwa tingkat pengangguran terbuka di Pulau Jawa sebesar 106.4933\% apabila variabel UMP, PDRB dan inflasi konstan.

2. Variabel PDRB berpengaruh negatif terhadap tingkat pengangguran terbuka dengan koefisien regresi sebesar -7.87 artinya jika variabel PDRB mengalami kenaikan $1 \%$ maka akan menurunkan tingkat pengangguran terbuka di Pulau Jawa sebesar $7.87 \%$.

3. Variabel UMP berpengaruh negatif terhadap tingkat pengangguran terbuka dengan koefisien sebesar -0.22 artinya jika variabel UMP mengalami kenaikan $1 \%$ maka akan menurunkan tingkat pengangguran terbuka di Pulau Jawa sebesar $0.22 \%$.

4. Variabel Inflasi berpengaruh negatif terhadap tingkat pengangguran terbuka dengan koefisien regresi senilai -0.05 artinya jika variabel Inflasi mengalami kenaikan $1 \%$ maka akan menurunkan tingkat pengangguran terbuka di Pulau Jawa sebesar $0.05 \%$.

\section{Uji $\mathbf{R}^{\mathbf{2}}$ (Koefisien Determinan)}

Besarnya presentase pengaruh semua variabel independen terhadap nilai variabel dependen dapat diketahui dari besarnya koefisien determinasi $\mathrm{R}^{2}$ persamaan regresi. Hasil dari uji $\mathrm{R}^{2}$ dapat dilihat pada Tabel 3 berikut: 
Tabel 3. Hasil Uji $\mathrm{R}^{2}$

\begin{tabular}{cc}
\hline Variable & Coefficient \\
\hline R-squared & 0.934933 \\
\hline
\end{tabular}

Sumber : data sekunder diolah, 2017

Berdasarkan Tabel 3 menunjukkan nilai $\mathrm{R}^{2}$ sebesar 0.934933 , artinya total variasi tingkat pengangguran terbuka di provinsi Pulau Jawa mampu dijelaskan oleh variabel-variabel independen PDRB, UMP dan inflasi sebesar 93,35\% sedangkan sisanya $6,65 \%$ dijelaskan variabel lain diluar model.

\section{Uji F Simultan}

Uji statistik F pada dasarnya menunjukkan apakah semua variabel independen yang dimasukkan dalam model mempunyai pengaruh secara bersama-sama terhadap variabel dependen. Hasil uji F sebagai berikut :

Tabel 4. Hasil Uji F

\begin{tabular}{cc}
\hline Variable & Coefficient \\
\hline Prob(F-statistic) & 0.000000 \\
\hline
\end{tabular}

Sumber : data sekunder diolah, 2017

Berdasarkan estimasi panel data Tabel 4, nilai probabilitas $\mathrm{F}_{\text {statistik }}$ sebesar 0,0000 lebih kecil darinilai probabilitas $\operatorname{kritis}(\alpha=5 \%)$, maka hipotesis nol $\left(\mathrm{H}_{0}\right)$ ditolak dan menerima hipotesis alternatif $\left(\mathrm{H}_{\mathrm{A}}\right)$,artinya semua variabel independen mampu menjelaskan variabel dependen atau secara bersamasama variabel independen PDRB, UMP, dan inflasi berpengaruh signifikan terhadap variabel dependen tingkat pengangguran terbuka.

\section{Uji t Parsial}

Uji statistik t pada dasarnya menunjukkan seberapa jauh pengaruh masing-masing variabel independen secara individual dalam menerangkan variasi variabel dependen. Hasil uji t Parsial sebagai berikut :

Tabel 5. Uji t-statistik

\begin{tabular}{ccc}
\hline Variable & t-Statistic & Prob. \\
\hline PDRB & -3.301094 & 0.0018 \\
UMP & -0.162658 & 0.8714 \\
INF & -1.113952 & 0.2705 \\
\hline
\end{tabular}

Sumber : data sekunder diolah, 2017

Berdasarkan hasil uji t, variabel independen terhadap variabel dependen secara parsial pada Tabel 5, maka dapat disimpulkan :

1. Variabel PDRB memiliki nilai probabilitas $t_{\text {statistik }}$ lebih kecil daripada nilai probabilitas kritis $\alpha=5 \%(0.0018<0,05)$. Dengan demikian hipotesis nol $\left(\mathrm{H}_{0}\right)$ ditolak dan menerima hipotesis alternatif $\left(\mathrm{H}_{\mathrm{A}}\right)$ berarti PDRB berpengaruh signifikan terhadap tingkat pengangguran terbuka di provinsi Pulau Jawa.

2. Variabel UMP memiliki nilai probabilitas $t_{\text {statistik }}$ lebih besar daripada nilai probabilitas kritis $\alpha=5 \%(0.8714>$
0,05). Dengan demikian hipotesis nol $\left(\mathrm{H}_{0}\right)$ diterima yang berarti UMP tidak berpengaruh signifikan terhadap tingkat pengangguran terbuka di provinsi Pulau Jawa.

3. Variabel inflasi memiliki nilai probabilitas $t_{\text {statistik }}$ lebih besar daripada nilai probabilitas kritis $\alpha=5 \%(0.2705>$ $0,05)$. Dengan demikian $\mathrm{H}_{0}$ diterima yang berarti Inflasi tidak berpengaruh signifikan terhadap tingkat pengangguran terbuka di provinsi Pulau Jawa.

\section{Uji Asumsi Klasik}

Terdapat empat uji asumsi klasik yang digunakan dalam penelitian ini, yaitu uji normalitas, multikolinearitas, uji heteroskedastisitas dan uji autokorelasi.

\section{Uji Normalitas}

Uji normalitas merupakan uji yang dilakukan untuk mengevaluasi apakah nilai residual dari model yang dibentukberdistribusi normal atau tidak. Konsep pengujian uji normalitas menggunakan pendekatan Jarque-berra test. Hasil dari uji normalitas dapat dilihat pada gambar 1 berikut:

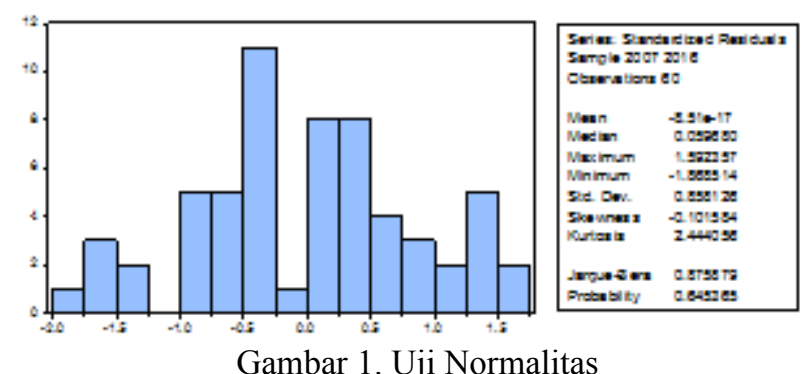

Sumber : data sekunder diolah, 2017

Berdasarkan Gambar 1 nilai probabilitas $\mathrm{JB}_{\text {statistik }}$ sebesar 0,645365 lebih besar dari nilai probabilitas kritis $(\alpha=5 \%)$, dapat ditarik kesimpulan bahwa model panel data tersebut terdistribusi normal karena nilai probabilitas $\mathrm{JB}_{\text {statistik }}$ lebih besar dibanding nilai probabilitas kritis $\alpha=5 \%$.

\section{Uji Multikolinearitas}

Uji multikolinieritas merupakan pengujian dari asumsi yang berkaitan bahwa antara variabel-variabel bebas dalam suatu model tidak saling berkorelasi satu dengan yang lainnya.. Dalam penelitian ini menggunakan nilai matrik korelasi untuk mendeteksi adanya multikolinearitas. Apabila nilai matrik korelasi melebihi $80 \%(0,8)$ maka variabel-variabel bebasnya memiliki hubungan yang tinggi dan cenderung terkena multikoliniearitas (Gujarati, 2013:429). Berdasarkan pengujian diperoleh hasil sebagai berikut :

Tabel 6. Uji Multikolinearitas

\begin{tabular}{cccc}
\hline & LOGPDRB & LOGUMP & INF \\
\hline LOGPDRB & 1.000000 & 0.246433 & -0.108135 \\
LOGUMP & 0.246433 & 1.000000 & -0.196504 \\
INF & -0.108135 & -0.196504 & 1.000000 \\
\hline
\end{tabular}

Sumber : data sekunder diolah, 2017

Dari matriks korelasi Tabel 6 tersebut terlihat bahwa hubungan antara masing-masing variabel bebas (PDRB, UMP dan inflasi) semua berada di bawah $80 \%$ atau 0,8 (rule 
of thumb) sehingga dapat dinyatakan tidak terdapat masalah multikolinearitas dalam model penelitian.

\section{Uji Autokorelasi}

Hasil penelitian menggunakan Durbin Watson untuk menguji ada atau tidaknya masalah autokorelasi dalam model, dengan kriteria $0<\mathrm{dw}<\mathrm{dl}$ atau $0<0.845610<1,4797$ maka terdapat masalah dalam model penelitian namun, dari pengujian panel data, model terbaik yang terpilih adalah Fixed Effect Model (FEM), dari hasil tersebut dapat dinyatakan tidak perlu diadakan uji autokorelasi. Hal ini sesuai dengan yang dijelaskan Nachrowi dan Usman dalam Ekananda (2016:166), apabila dalam pemilihan teknik analisis panel data ditentukan Fixed Effect Model (FEM) adalah model yang terbaik, maka masalah autokorelasi dapat diabaikan, karena tidak dibutuhkan asumsi terbebasnya model dari serial korelasi.

\section{Uji Heteroskedastisitas}

Uji Heteroskesdastisitas ini digunakan untuk mengetahui apakah dalam suatu model regresi terjadi ketidaksamaan variabel dan residual dari satu penagmatan ke pengamatan yang lain. Diagnosis adanya heteroskedastisitas secara kuantitatif dalam suatu regresi dapat dilakukan dengan melakukan pengujian korelasi uji Glesjer (Glesjer test). Uji ini dilakukan dengan membuat model regresi yang melibatkan nilai absolut residual, sebagai variabel dependen, terhadap semua variabel independen (Algifari, 2011:86). Hasil uji heteroskedastisitas sebagai berikut:

Tabel 7. Uji Heterokedastistas Menggunakan Uji Glesjer

\begin{tabular}{ccccc}
\hline Variable & Coefficient & Std. Error & t-Statistic & Prob. \\
\hline PDRB & -0.975048 & 0.994691 & -0.980252 & 0.3316 \\
UMP & 0.617859 & 0.573033 & 1.078226 & 0.2860 \\
INF & -0.026061 & 0.019819 & -1.314950 & 0.1944
\end{tabular}

Sumber : data sekunder diolah, 2017

Berdasarkan hasil pengujian heterokedastisitas menggunakan uji Glejser, variabel dependen terhadap variabel independen secara parsial pada Tabel 6, maka dapat dipaparkan sebagai berikut :

1. Variabel PDRB memiliki nilai probabilitas $t_{\text {statistik }}$ lebih besar daripada nilai probabilitas kritis $\alpha=5 \%(0.3316>$ 0,05). Dengan demikian $\mathrm{H}_{0}$ diterima yang berarti variabel PDRB tidak terjadi masalah heterokedastisitas

2. Variabel UMP memiliki nilai probabilitas $t_{\text {statistik }}$ lebih besardaripada nilai probabilitas kritis $\alpha=5 \%(0.2860>0,05)$. Dengan demikian $\mathrm{H}_{0}$ diterima yang berarti variabel UMP tidak terjadi masalah heterokedastisitas.

3.Variabel inflasi memiliki nilai probabilitas $\mathrm{t}_{\text {statistik }}$ lebih besardaripada nilai probabilitas kritis $\alpha=5 \%(0.1944>0,05)$. Dengan demikian $\mathrm{H}_{0}$ diterima yang berarti variabel IPM tidak terjadi masalah heterokedastisitas.

\section{Pembahasan}

Pengaruh Produk Domestik Bruto Regional (PDRB) terhadap Tingkat Pengangguran Terbuka di Pulau Jawa
Dari hasil estimasi menunjukkan bahwa Produk Domestik Regional Bruto (PDRB) berpengaruh negatif dan signifikan terhadap tingkat pengangguran terbuka di setiap Provinsi Pulau Jawa tahun 2007-2016, yang ditunjukkan dengan nilai coefficient -7.87. Coefficient PDRB yang memiliki arah negatif menunjukkan bahwa setiap kenaikan 1\% PDRB akan menurunkan tingkat pengangguran terbuka di setiap Provinsi Pulau Jawa sebesar 7.87\%. Hal ini berarti dengan meningkatnya PDRB diikuti dengan menurunnya tingkat pengangguran terbuka di setiap Provinsi Pulau Jawa. Hasil penelitian tersebut sesuai dengan hukum Okun yang menyatakan bahwa jika terjadi peningkatan terhadap tingkat pengangguran terbuka di suatu Negara maka hal tersebut setara dengan terjadinya penurunan PDRB sebesar 2 persen. Sehingga apabila terjadi peningkatan terhadap PDRB berarti telah terjadi kenaikan terhadap produksi barang dan jasa. Kenaikan produksi barang dan jasa mengakibatkan kenaikan terhadap faktor-faktor produksi yang salah satunya adalah naiknya permintaan tenaga kerja sehingga menurunkan tingkat pengangguran. Begitu pula sebaliknya jika terjadi penurunan terhadap PDRB maka terjadi penurunan pada faktor-faktor produksi yang salah satunya turunnya permintaan tenaga kerja dan mengakibatkan naiknya tingkat pengangguran.

Hubungan yang signifikan antara PDRB terhadap tingkat pengangguran terbuka menunjukkan bahwa tingkat pengangguran terbuka di setiap Provinsi Pulau Jawa dipengaruhi oleh produk domestik bruto. Dikutip dari Badan Pusat Statistik (2016), pada tahun 2011-2015 pertumbuhan PDRB mengalami peningkatan yang baik setiap tahunnya, di mana penyumbang PDRB tertinggi di setiap provinsi Pulau Jawa yaitu sektor industri pengolahan dan perdagangan besar dan eceran; reparasi mobil dan sepedah motor. Peningkatan pada nilai PDRB menandakan telah terjadi kenaikan terhadap nilai tambah output atau penjualan barang dan jasa di suatu wilayah. Semakin besar output atau penjualan barang dan jasa yang dilakukan perusahaan akan mengakibatkan kenaikan terhadap faktor-faktor produksi seperti tenaga kerja. Peningkatan permintaan tenaga kerja yang disebabkan oleh kenaikan faktor-faktor produksi suatu perusahaan akan menurunkan tingkat pengangguran khususnya di Pulau Jawa.

\section{Pengaruh Upah Minimum Provinsi (UMP) terhadap Tingkat Pengangguran Terbuka di Pulau Jawa}

Dari hasil estimasi menunjukkan bahwa Upah Minimum Provinsi (UMP) berpengaruh negatif dan tidak signifikan terhadap tingkat pengangguran terbuka di setiap Provinsi Pulau Jawa tahun 2007-2016, yang ditunjukkan dengan nilai coefficient -0.22. Coefficient UMP yang memiliki arah negatif menunjukkan bahwa setiap kenaikan 1\% UMP akan menurunkan tingkat pengangguran terbuka di setiap Provinsi Pulau Jawa sebesar $0.22 \%$. Hasil tersebut sesuai dengan teori Keynes yang menyatakan jika tingkat upah naik akan berpengaruh pada penurunan tingkat pengangguran. Ketika tingkat upah naik maka pendapatan pun akan naik, dampaknya adalah daya beli akan naik dan tentu saja pengeluaran masyarakat akan bertambah, maka kapasitas produksi akan ditingkatkan sesuai dengan permintaan barang dan jasa, sehingga perusahaan akan menambah tenaga kerjanya dan penggunaan tenaga kerja penuh (full employment) akan tercapai. Sebaliknya jika tingkat upah turun akan berpengaruh pada naiknya tingkat pengangguran. 
Hasil penelitian menunjukkan hubungan antara UMP dengan tingkat pengangguran terbuka tidak signifikan dengan koefisien arah regresi yang diperoleh sesuai denganhipotesis dan teori-teori yang telah dikemukakan.

Ketidaksignifikan UMP dalam mempengangurhi pengangguran terbuka dapat dilihat berdasarkan data bahwa peningkatan UMP di Pulau Jawa dari tahun 2007 sampai dengan tahun 2016 tidak selalu diiringin dengan penurunan tingkat pengangguran terbuka. Seperti halnya kenaikan UMP di Provinsi DKI Jakarta tahun 2011; Jawa Barat tahun 2013,2015, dan 2016; Jawa Tengah tahun 2011 dan 2013; DI Yogyakarta tahun 2014 an 2015; Jawa timur tahun 2011,2013 dan 2015; Banten 2011 yang terjadi kenaikan tingkat pengangguran. Hal ini berati kenaikan UMP yang terjadi di setiap Provinsi Pulau Jawa tidak menyerap tenaga kerja yang ada sehingga pengangguran tidak berkurang. Peraturan pengupahan telah diatur dalam UU No.13 Tahun 2003 dan PP No.78 Tahun 2015 merupakan usaha pemerintah untuk melindungi pekerja dari upah murah yaitu dengan penetapan upah minimum yang ditetapkan setahun sekali oleh Gubernur. Selain itu peraturan tersebut juga membantu para pencari kerja agar bisa masuk ke pasar kerja, dan melindungi dunia usaha agar bisa berkembang sehingga dapat menciptakan lapangan kerja baru untuk mengurangi pengangguran.

\section{Pengaruh Inflasi terhadap Tingkat Pengangguran Terbuka di Pulau Jawa}

Dari hasil estimasi menunjukkan bahwa Inflasi berpengaruh negatif dan tidak signifikan terhadap tingkat pengangguran terbuka di setiap Provinsi Pulau Jawa tahun 2007-2016, yang ditunjukkan dengan nilai coefficient -0.05 . Coefficient Inflasi yang memiliki arah negatif menunjukkan bahwa setiap kenaikan 1\% Inflasi akan menurunkan tingkat pengangguran terbuka di setiap Provinsi Pulau Jawa sebesar 0.05\%. Hasil tersebut sesuai dengan teori kurva Phillips yang menyatakan jika inflasi naik akan berpengaruh pada penurunan tingkat pengangguran. Ketika inflasi naik berarti telah terjadi kenaikan harga barang, dimana salah satu penyebab kenaikan harga barang adalah tuntutan kenaikan upah, sehingga untuk mengatasi biaya produksi dan operasi maka harga produk dijual dengan harga yang relatif mahal dari sebelumnya. Harga produk yang naik membuat perusahaan termotivasi untuk menambah jumlah produksi dengan menambah jumlah tenaga kerja sehingga pengangguran berkurang.

Ketidaksignifikan Inflasi dalam mempengangurhi pengangguran terbuka di Pulau Jawa disebabkan oleh inflasi yang terjadi selama kurun waktu 2007 - 2016 masuk kedalam kategori ringan, kecuali pada tahun 2008 terjadi peningkatan inflasi dari status semula ringan menjadi sedang, yaitu berkisar $10-14 \%$. Walaupun demikian, nilai ini masih mendekati kategori inflasi ringan dan pada tahun selanjutnya langsung mengalami penurunan. Tingkat inflasi di Pulau Jawa selalu mengalami pasang surut dari tahun ketahun. Sebenarnya parah atau tidaknya inflasi bersifat relatif, karena berat atau ringannya suatu inflasi bergantung pada kekuatan ekonomi masyarakat yang mengalami inflasi. Kondisi inflasi ringan justru mempunyai dampak yang positif dalam arti untuk perekonomian yang lebih baik. Namun apabila inflasi tersebut dalam kondisi berat dan tidak terkendali, keadaan perekonomian menjadi tidak setabil karena harga meningkat dengan cepat, hai itu menyebabkan masyarakat menjadi terpuruk dan dapat menurunkan kesejahteraan masyarakat.

\section{Simpulan}

Berdasarkan hasil analisis dari penelitian, maka dapat diperoleh kesimpulan sebagai berikut :

Produk Domestik Regional Bruto (PDRB) memiliki pengaruh negatif dan signifikan terhadap tingkat pengangguran terbuka di setiap provinsi Pulau Jawa periode tahun 2007 - 2016. Hal ini berarti bahwa semakin tinggi Produk Domestik Regional Bruto (PDRB) maka semakin berkurang tingkat pengangguran terbuka, Upah Minimum Provinsi (UMP) memiliki pengaruh negatif dan tidak signifikan terhadap tingkat pengangguran terbuka di setiap provinsi Pulau Jawa periode tahun 2007 - 2016. Hal ini berarti bahwa berapapun nilai dari UMP meningkat,maka tidak akan berpengaruh terhadap tingkat pengangguran terbuka, Inflasi memiliki pengaruh negatif dan tidak signifikan terhadap tingkat pengangguran terbuka di setiap provinsi Pulau Jawa periode tahun 2007 - 2016. Hal ini berarti bahwa berapapun nilai dari inflasi meningkat,maka tidak akan berpengaruh terhadap tingkat pengangguran terbuka.

\section{Referensi}

Amir, Amri. 2007. Pengaruh inflasi dan pertumbuhan ekonomi terhadap pengangguran di Indonesia. Jurnal Inflasi dan Pengangguran, Vol.1 (No. 1).Hal: 4-9.

Ananta, Anis. 1990 Jurnal Inflasi dan Pengangguran. Jurnal Ekonomi Vol.1. No. 1.2000

Badan Pusat Statistik Daerah Istimewa Yogyakarta. 2015. Daerah Istimewa Yogyakarta Dalam Angka 2015. Yogyakarta: Badan Pusat Statistik Provinsi Daerah Istimewa Yogyakarta

Badan Pusat Statistik DKI Jakerta. 2016. Jakarta Dalam Angka 2016. Jakarta: Badan Pusat Statistik Provinsi DKI Jakarta

Badan Pusat Statistik Jawa Barat. 2016. Jawa Barat Dalam Angka 2016. Bandung: Badan Pusat Statistik Provinsi Jawa Barat

Badan Pusat Statistik Jawa Tengah. 2016. Jawa Tengah Dalam Angka 2016. Semarang: Badan Pusat Statistik Provinsi Jawa Tengah

Badan Pusat Statistik Jawa Timur. 2016. Jawa Timur Dalam Angka 2016. Surabaya: Badan Pusat Statistik Provinsi Jawa Timur

Gujarati Damodar.2004. Basic Econometrics (Ekonometrika Dasar). Alih bahasa Sumarno Zain. Jakarta: erlangga

Sukirno, Sadono. 2006. Mikro Ekonomi teori Pengantar. Jakarta: Raja Grafindo Persada. 